\title{
Constructing Social Problems in an Age of Globalization: A French-American Comparison
}

\author{
Rodney Benson \\ New York University
}

\author{
Abigail C. Saguy \\ University of California
}

Despite growing academic interest in political and cultural globalization, sociologists have failed to systematically account for the factors that favor cross-national convergence or divergence in the form or content of public political debates in news media. This article uses two original data sets on American and French news reporting on immigration and sexual harassment to test the effects of four factors potentially relevant to such convergence or divergence: 1) cultural repertoires, 2) legal constraints, 3) journalistic field relations to the state and market and competition among journalistic outlets, and 4) global position of nation-states. Differences in dominant national cultural repertoires correlate with persistent cross-national variations in media frames. Legal reform related to the two issues offers a strong explanation of shifts in framing over time. Lesser news media autonomy vis-à-vis the state is associated with fewer journalistic enterprise stories on immigration and less reporting on sexual harassment scandals, while greater competition may make sensationalized reporting on immigration more likely. America's dominant position in the global political economy correlates with substantially greater visibility of U.S. policies and personalities in France, than vice versa. There is some evidence for greater, crossenational divengence in issue frames over time, as U.S. global visibility and influence have increased.

$\mathrm{D}$ espite much talk about the increasing global diffusion of political ideas, ideologies, and practices, there has still been relatively lit-

Direct correspondence to Abigail C. Saguy, UCLA Department of Sociology, 264 Haines Hall, Los Angeles, CA 90095 (saguy@soc.ucla.edu), or Rodney Benson, NYU Department of Culture and Communication, 239 Greene Street, 7th Floor, New York, NY 10003-6674 (rodney.benson@nyu.edu). The author names appear alphabetically; both authors contributed equally to this article. Several revisions of this paper have been presented at various sociology colloquia and conferences; the authors thank their many colleagues for their comments and questions. Special thanks to Richard Arum, Barry Glassner, Jerry Jacobs, Gail Kligman, Bill Roy, Marc Scott, Roger Waldinger, Bruce Western, and three anonymous $A S R$ reviewers. Thanks to the UCLA ATS Statistical Consulting group for technical advice and to Rachel Berger, Jane Mabe, and Kevin Riley for research assistance. tle exploration of the extent to which debates in national news media about similar social problems have come to resemble one another, as well as the causes for such convergence or lack thereof. Some studies provide evidence of gradual, if uneven, convergence in certain journalistic practices and aspects of news content (Tunstall 1977; Castells 1997) and form (Barnhurst and Nerone 2001), producing what McQuail (1994) has termed an "international media culture.” Other studies, however, highlight continuing cross-national differences in journalistic norms and values (Padioleau 1985; Patterson and Donsbach 1996; Esser 1998; Weaver 1998; Deuze 2002) and point to significant differences in the treatment of the same international media events (Hallin and Mancini 1984; Gurevitch et al. 1991) or of similar kinds of issues (Ferree et al. 2002; Benson 2000; Saguy 2002). Unfortunately, these diverse and conflicting findings have not been synthesized either theoretically or empirically. As Guillén 
(2001) observes, comparative sociological research is needed to provide a better "handle on the patterns according to which the causes and effects of globalization change from one setting to another."

In this article, we attempt to address this important hole in the literature. To this end, we draw on social problems constructivism, cultural sociology, and field theory to develop a series of hypotheses about differences and similarities in social problem constructions across national contexts, which we test with original data on U.S. and French reporting on immigration and sexual harassment. The United States and France offer a fruitful case study for cross-national comparative research. Both are large Western, industrialized democracies with long histories of immigration and comparable rates of female participation in the labor force. Although both countries have pretensions to a universal model of justice, they have often defined these models in opposition to one another (see Faure and Bishop 1992; Gordon and Meunier 2001). Despite the greater global power of the United States, many French and Americans stili consider France (and Europe more generally) to be culturally superior and thus look to France as a model for artistic and intellectual innovation (Lamont 1987; Clark 1987). France is also commonly regarded as the most consistent and forceful First-World voice of resistance to American political and cultural hegemony, expressing concerns about American imperialism that many other Western and non-Western nations share less vocally.

Despite some important national differences in the social conditions and practices related to immigration and sexual harassment, the similarities are great enough to make a cross-national comparison feasible and productive. For instance, although there is a common perception that the level of immigration is much higher in the United States than in France, the French foreign-born population was quite comparable to that of the United States during the period in our study. U.S. foreign-born percentage of population increased from 5.3 percent in 1974 to 8.7 percent in 1994 (Fetzer 2000: 165-166, citing U.S. Census data), whereas French foreign-born population increased from 7.9 percent in 1968 to 9.4 percent in 1990 (Fetzer 2000: 161). While the foreign-born percentage of population is much higher in Southern California or New
York than for the rest of the United States, the same can also be said for France in the metropolitan regions around Paris and Marseilles. There is also evidence of "growing similarity" between France and the United States, as well as among other major industrialized democracies, in terms of immigration control measures, the efficacy of such measures, social integration policies, and the public's evaluations of immigration levels and government immigration policies (Cornelius et al. 1995:4).

Likewise, we can deduce from existing survey data that a sizeable percentage of both American and French women have been confronted with sexual harassment in the workplace, even if methodological differences in survey design make hard-and-fast comparisons difficult (see U.S. Merit Systems Protection Board 1981 and Harris 1991). In that most victims are women harassed by men, it is significant that the rate of female employment is comparable in the two countries. The EEOC estimates that 47.1 percent of the American workforce was female in 2000, up from 32 percent in 1968 (O'Connor et al. 1999). The comparable statistics for France are 47.6 percent in 1998 and 34 percent in 1968 (INSEE 1998).

Despite important similarities in the objective conditions of immigration and sexual harassment, one might expect American and French media representations of these issues to vary due to different political-cultural traditions in each country, particularly related to issues of identity politics and group rights. For instance, from slavery to affirmative action, to the official census, the United States has institutionalized traditions of categorizing people by group - especially "race" and ethnic - affiliation, and racial, gender, religious, and other identities provide a basis for political mobilization (see Skrentny 2001; Steinberg 1981). In contrast, there is less of a political and cultural basis in France for categorizing people according to racial, ethnic, or religious affiliation. By separating the church and state, the Third Republic hoped to confine customs and beliefs to the "private sphere," meaning both that the state should not segregate citizens according to these criteria and that citizens should not "politicize" these differences (Noiriel 1996). Consequently, and in accordance with republican principles, France's census does not gather information about race, ethnicity, or religion, 
which subsequently makes it difficult to measure racial discrimination. Without an objective measure of racial inequality, it has been difficult to make this a political rallying point. While racial categorization in the United States can serve to reify "races" and reinforce racism, the lack of statistics in France on racial disparity can obscure discrimination and racism. In the United States, the politicization and theorization of racism has provided a basis for denouncing other forms of group-based discrimination like sexism. In France, opponents of the politicization of group identity can and do appeal to long political traditions of an assimilating model of nationhood (Brubaker 1992; Scott 1997).

Examining media reporting on immigration and sexual harassment together has several advantages over a one-issue study. As two issues related to identity politics and group rights, these cases are particularly useful for ascertaining the effect that French and U.S. political traditions and ideas of civil society have on the representation of these sorts of issues. Yet, since these two issues are distinct, consistent findings across the social problem cases strengthen the study's generalizability. Moreover, since the time frames of legal change are discrete by issue, we can tease out the effect of specific legal definitions from that of broad cultural conceptions. Finally, the temporal proximity of the two public political debates-with French media discussions of immigration preceding those of sexual harassment - allows us to tentatively examine social problem interaction (Best 2001).

In what follows, we review the relevant literature in social problems, cultural repertoires and field theory and then link these theories to the particular history of immigration and sexual harassment in our two national cases to generate hypotheses about how the U.S. and French press will converge or diverge in their "framing" of immigration and sexual harassment. By framing, we mean the selection and emphasis of "some aspects of a perceived reality ... in such a way as to promote a particular problem definition" (Entman 1993: 52; see also Ryan 1992). In a methodology section, we review how the data were collected and coded to test our hypotheses. These hypotheses are evaluated for the cases of U.S. and French framing of immigration and of sexual harassment in two separate sections. We conclude with a general discussion of how a structural-relational theo- ry of culture, bolstered by future research, can identify and explain salient social patterns in national media representations of social problems.

\section{LITERATURE REVIEW: SOCIAL PROBLEMS, CULTURAL REPERTOIRES, AND FIELDS}

The "social construction of social problems" research tradition attributes the dominant framing of a social problem to three general causes: claims-maker activities, media practices, and cultural themes or resonances (Gamson and Modigliani 1989; Beckett 1996). This literature shows that activists, officials, and experts attempt to define a problem in various ways, but national culture and the media industry set limits on which definition will prevail in the public sphere. Different national societies can come to consider the same conditions problematic for a variety of reasons. Similar economic, technological, or political changes can occur within the societies or specific changes can occur in, say, the extent or nature of sexual harassment or immigration. Alternatively, overt efforts can be made to diffuse social problem constructions from one country to another. According to two commentators, "the greater the cultural dominance of one nation by another, the more likely the diffusion of social problem claims will be one-way, rather than a reciprocal process" (Sacco and Ismaili 2001: 25), suggesting that U.S. media reporting will be diffused more in France than vice versa.

Diffusion, however, is not the same as imitation, the latter of which is said to be hindered by cross-national differences in cultural traditions (Jenkins 1992; Victor 1998; Lee 2001). Since no two nation-states can be said to share the exact same culture, one would expect to see particular social problem definitions fail to diffuse or be significantly redefined when they travel. If national cultures are different enough, foreign ideas and icons may even provoke a backlash (Barber 1995). In the case of France, there is a popular conception that antiAmericanism is so great that any idea labeled as "American" is unlikely to succeed, although numerous historians of French-American relations have shown that French attitudes towards the United States are complex and ambivalent (Kuisel 1993; Fantasia 1995). 
In cultural sociology, Lamont and Thévenot (2000: 8) identify "national cultural repertoires" as "relatively stable schemas of evaluation that are used in varying proportion across national contexts." They show that U.S. political discourses are dominated by "market-based arguments," in which people are judged by their performance in the labor market and equal access to paid employment is highly valued (Lamont and Thévenot 2000: 14). Under such market logic, each person's moral worth is partly contingent on their employment success, making employment discrimination particularly offensive and eroding support for payments to the unemployed. In contrast, French discourses are dominated by "civic solidarity arguments," which stress egalitarian and non-materialist values. All French persons are thus entitled to basic economic and social rights by virtue of their common humanity. However, in practice, this solidarity is often bounded to the group of people who share "French culture" (e.g., appreciation and knowledge of French cuisine, French art, and "proper" French diction), are secular Catholics or at least quiet about non-Catholic religious convictions, and generally do not politicize racial, ethnic, religious, or gender group identity (see Lamont 2000). To the extent that these distinct national cultural repertoires are shared by journalists and their sources, we would expect to see more market rationality in the U.S. press and more civic solidarity arguments in the French press.

Related to, but potentially supplementing the repertoires model, are approaches which emphasize how culture is embedded in institutions (e.g., Friedland and Alford 1991; Saguy 2003; Swidler 2001). This approach calls attention to the greater capacity of some institutions - such as that of the law-to legitimize and otherwise give force to some cultural meanings over others. Based on this work, we would expect media reporting on immigration and sexual harassment to reflect differences in how these issues are addressed in national laws.

Finally, field theory emphasizes how the immediate cultural and social-organizational environment ("field") shapes the production of news discourses. The journalistic field is only one among many semi-autonomous fields of contemporary western societies, including the social scientific, political, and economic fields (Bourdieu 1993; DiMaggio and Powell 1991).
Field boundaries are established through struggles for professional autonomy; once established, fields tend to perpetuate distinct cultural logics, although their autonomy is constantly threatened by closely related fields. As social spaces, fields may also be distinguished by the density and intensity of internal relations. Crossnational differences in the French and U.S. national journalistic fields, such as distinct media routines, degree and type of competition among media outlets, or level of dependency on the political or economic fields, could thus shape the content or form of national media reporting (Benson 1999, 2004).

Bourdieu (1998: 41) further acknowledges that for a journalistic field analysis to be complete, "the position of the national media field within the global media field would have to be taken into account," for example, "the economic-technical, and especially, symbolic dominance of American television, which serves a good many [non-American] journalists as both a model and a source of ideas, formulas and tactics." This suggests that French media accounts may be more heavily influenced by U.S. accounts than vice versa.

\section{HYPOTHESES}

To the extent that dominant cultural repertoires have a broad-ranging power to structure public debate on a variety of issues, and that these vary systematically between the United States and France, we should see robust differences in American and French media framing of immigration and sexual harassment. Specifically, due to their focus on civic solidarity, we expect the French press to express more concern about social problems (e.g., working and living conditions) that immigrants, like other economically underprivileged groups, typically encounter, as well as cultural problems immigrants face in adapting to France. In contrast, we expect American media framing of immigration to focus most heavily on the fiscal problems created by immigrants, since market-based rationality is especially suspect of government "hand-outs." On the other hand, in that French civic solidarity is bounded to those considered culturally French, French news media stories will be more likely than U.S. stories to stress the cultural problems for society created by immigrants' failure to integrate. 
In the case of sexual harassment, we expect to find that U.S. media frame sexual harassment as a form of sex-based discrimination in employment, since this framing stresses the importance of equal employment opportunities through the job market (market rationality). In contrast, the French media should be more likely to stress civic solidarity by, for instance, condemning sexual harassment not because it is a form of sex-based discrimination in employment but because it constitutes an abuse of professional power over ordinary workers. Such a framing is an implicit critique of economic inequality and portrays sexual harassment as an injustice and a violation of personal integrity, three key concerns of French civic solidarity. As Lamont (2000: 164, 167) writes: “. . . the French believe that personal integrity often requires one to put principles above material interests ... solidarity is also understood to mean standing up against injustice at work or elsewhere for the benefit of others."

This leads to the following hypothesis focused on the content of media reporting in our two cases:

Hypothesis 1.1 (Cultural repertoires): American and French news media framing of immigration and sexual harassment will differ in similar ways over time, reflecting marketbased rationality in the United States and an emphasis on civic solidarity (especially for those considered culturally French) in France. Specifically, the French media will be more likely than the American media to report on social and cultural problems faced by immigrants but also on cultural problems created for society by some immigrants' failure to assimilate. The U.S. media will be more likely to report on fiscal problems created by immigration. The French media will be more likely to frame sexual harassment as an abuse of professional power, while the U.S. media will be more likely to frame it as a form of sexbased discrimination in employment.

In contrast to cultural repertoires, which are relatively constant in each society, laws and jurisprudence have changed markedly during the period under study. To the extent that these exert additional cultural force, we should expect media framing to shift in line with changes in the legal realm.

That said, the first legal difference-concerning approaches to racial discriminationhas been relatively constant during the time period of our study, during which France has prohibited the gathering of ethnic and racial data in an effort to promote a "color-blind" society. While France has enacted anti-racist discrimination laws since the early 1970 s, these have tended to target racist and anti-Semitic violence or speech, rather than discrimination in employment, education, or housing (Bleich 2001). Compared to the United States, or to Great Britain, French employment discrimination laws have been less often applied and discrimination has been more narrowly defined (Banton 1994; Bleich 2001). Unlike in the United States, where "indirect discrimination"-or practices that do not explicitly discriminate against, say, blacks or women but have a "disparate impact" on those groups - has been recognized for over three decades, during the time of our study French law only recognized discriminatory intent. ${ }^{1}$

U.S. and French policies regarding the fiscal costs of social programs for immigrants were not markedly different through the 1980s. However, during the early 1990s, recent immigrants and especially illegal immigrants were increasingly stigmatized in a broader backlash against the welfare state in the United States (Gans 1995). Notably, in 1994, the bipartisan U.S. Commission on Immigration Reform recommended substantial cuts in the government benefits received by undocumented immigrants (Calavita 1996: 291), and California voters approved Proposition 187, a ballot initiative ending all social services, including public

${ }^{1}$ In Griggs v. Duke Power Co., 401 U.S. 424 (1971), the U.S. High Court ruled that the use of a pre-employment test having discriminatory impact violates Title VII, despite the absence of discriminatory intent. Law 2001-1066, passed on November 162001 , introduced the concept of indirect discrimination to French law (Journal Officiel, LOI no 2001-1066 du 16 novembre 2001 relative à la lutte contre les discriminations . Journal Officiel, no. 267: 18311, [Paris, 2001]). It is too soon to tell what the concrete effect of this will be on French jurisprudence. 
education, to illegal immigrants. In contrast, there has been little or no effort on the part of the French government to restrict welfare benefits to immigrants.

In France, on the other hand, the cultural identity of immigrants has been politically salient since the mid 1970s, whereas this has not been true for the United States. During his 1974-1981 administration, conservative President Giscard d'Estaing enacted policies to preserve diverse immigrant cultures so as to maintain good political relations with the sending countries, helping to ensure the immigrant workers' eventual return. During the presidential race of 1981, socialist François Mitterrand made immigrant rights a campaign issue. Once victorious, he enacted policies, such as the legal recognition of immigrant-led associations, which extended the "right to be different" to non-European immigrants and their descendants who had no intention of leaving France (Vichniac 1991). In 1983, the anti-immigration National Front party led by Jean-Marie Le Pen began winning local elections, in part by attacking this pro-cultural diversity stance. Forthe rest of the decade, questions surrounding the desirability of cultural diversity in the public sphere prompted sharp debates. A new official consensus in favor of "integration" over multiculturalism was expressed in reports by the Commission de la Nationalité in 1988 and the Haut Conseil à l'Intégration in 1991, and supported by social policies of the French Social Action Fund for Immigrant Workers and Their Families (or FAS; see Bleich 2001: 272-77; Body-Gendrot and Schain 1992; Favell 2001).

In the United States, state and federal courts have defined sexual harassment since the late 1970 s as a civil offense, specifically a form of sex discrimination in employment under Title VII of the Civil Rights Act of 1964, which makes it illegal to discriminate on the basis of race, color, religion, sex, or national origin. ${ }^{2}$ In France, legislative debates beginning in 1991 culminated in the 1992 penal statute, ${ }^{3}$ which defined sexual harassment as an abuse of power and a form of sexual violence akin to rape. While a rapist uses physical force to obtain sex-

2 Title VII of the Civil Rights Act of 1964, 42 U.S.C. $\S \S 2000$ e to $2000 \mathrm{e}-17$ (1994).

${ }^{3}$ Art. 222-33 du nouveau Code Pénal. ual contact with the victim, a sexual harasser-according to this conception-uses workplace authority to try to coerce the victim into having sexual relations (Saguy 2000). ${ }^{4}$ As French immigration policies have been firmly "color-blind," so French sexual harassment laws have been gender-blind, by recognizing only professional hierarchical inequalities and not gender inequalities. This discussion informs our second hypothesis focused on news content:

Hypothesis 1.2 (Institutional—Law): U.S. media framing of immigration will emphasize welfare abuse (fiscal problems), especially from the early 1990 s on, and racial discrimination for the entire period of this study (1970s-1990s). In contrast, during the early 1980s when the French socialist government enacted pro-cultural diversity policies, French media framing will include more positive cultural diversity frames and will emphasize cultural problems for immigrants. After the late 1980s, French media framing will focus on cultural problems created by immigrants as a barrier to cultural integration. U.S. media will frame sexual harassment as sex discrimination in employment, whereas the French media will frame it as an abuse of professional hierarchical power and as a form of violence, and these patterns will be most pronounced after 1991.

National differences in the journalistic field's dependence on the market or the state may also influence the genres of media reporting, the focus of our next two hypotheses. In most countries, the journalistic field is marked by its "double dependency" (Champagne 2005) on the market (for funding and advertising) and on the state (for information, but also for direct or indirect subsidies), but the American journalistic

\footnotetext{
${ }^{4}$ Before 2002, French law limited sexual harassment to instances involving abuse of power and categorized sexual harassment as a form of sexual violence. In 2002, the law was extended to apply also to coworkers, but sexual harassment remained in the category of sexual violence (Saguy 2003). Since our media sample precedes these legal reforms, however, the earlier laws are the pertinent reference here.
} 
field is much more market-dominated than its counterparts in other western nation-states including France (Schudson 1995; Benson 2005; Hallin and Mancini 2004). Since the mid1980s, French advertising's percentage of gross domestic product has been about six-tenths of one percent or less than one half the relative level of advertising in the United States (Benson 2005). Advertising continues to provide just 50 percent of revenues for the French newspaper press as a whole and less than one-third for many of the leading French national dailies, versus 75-80 percent for most American newspapers, including the national elite press (Devillard et al. 2001: 28; Baker 1994: 16). American news media are also increasingly owned by large publicly-traded companies that demand profit maximization (Bagdikian 2000); this is not the case in France. However, there is some evidence of an increasing commercialization of the French media in recent years, primarily due to the privatization of much of the previously state-owned television system (Kuhn 1995; Bourdieu 1998).

Conversely, the French journalistic field is more state-dominated than its American counterpart. The French national government's financial and regulatory role vis-à-vis both television and the press has remained quite constant since the 1970s. Between 1970 and 1990, state aid to the press as a percentage of total press revenues ranged between 10 and 15 percent, among the highest levels of any European nation-states (Kuhn 1995: 40). At the same time, harsh defamation laws and wide-ranging restrictions on access to government documents have made it difficult for French journalists to investigate either the private lives of politicians or inner workings of government agencies (Derieux 2001).

Commercialization has been accused of causing many ills, but perhaps one of the most constant hypothesized effects is "sensationalism" (e.g., Freiberg 1981; Bennett 1983; Castells 1997). We hypothesize that news coverage will be more sensationalistic in the highly-commercialized American media, with slight convergence over time as the French media become somewhat more commercialized. State dominance of the press, for its part, is posited to limit journalistic autonomy vis-à-vis the government (Shoemaker and Reese 1991). In some cases, the government imposes penalties for certain kinds of reporting; in others, state subsidies can make newspapers "feel indebted to a government that has been so generous to them," thus serving as a "soft" control (de Tarlé 1980: 146). For both issues, journalist-initiated news stories, including investigations of government and especially of politicians' personal behavior, are expected to be less frequent in the French than in the American media.

The enduring legacy of the historical formation of the journalistic field, embodied in the taken-for-granted professional practices and beliefs of journalists, also shapes media attention and framing of social issues independently of external pressures (see Benson 2004). Nevertheless, for the particular cases at hand, the divergent French-American professional traditions ought to largely reinforce the social effects produced by overall field position in society. Specifically, the French "political/literary" press tradition, in valuing ideas over the latest news "scoop," should also contribute to lesser sensationalism. Likewise, French journalistic culture of not reporting on politicians' sex lives stouta, along with libel laws, limit French domestic sex scandals (see Padioleau 1985: 327; Courtois 1998; Thogmartin 1998: 269-72).

In the immigration case, we measure journalistic initiative and sensationalism by drawing on the news event typology developed by Molotch and Lester (1974) to identify three categories: 1) "routine habitual" stories, in which government, business or academic elites with "habitual" and easy access to journalists promote media coverage of an event; 2) "routine identical" events, such as a newspaper-sponsored poll or investigative journalism, in which journalists are both the news "promoters" and news "assemblers"; and 3) "scandals," when an event is done intentionally but in secret and then exposed by a third party. We consider that press coverage exhibits more autonomous initiative to the extent that more stories are selfgenerated or "routine identical" (e.g., independent investigations or analyses) versus political elite-generated or "routine habitual" (e.g., press conferences, statements, other political "media events"); sensationalism is measured by the proportion of scandal stories.

In the case of sexual harassment, we operationalize sensationalism by examining whether each article focused on or mentioned a sexual harassment scandal (e.g., Clarence Thomas' 
U.S. Senate confirmation hearings, the Tailhook scandal, or Paula Jones' lawsuit against Bill Clinton). To be considered a scandal, the incident had to involve a high-profile individual (e.g., national President) or institution (e.g., national military).

Stated as a hypothesis:

\section{Hypothesis 2.1 (Journalistic Field Domestic} Location): Because the American journalistic field is more market-dominated and the French journalistic field is more statedominated, American reporting on sexual harassment and immigration will be more sensationalistic but will also demonstrate more independent journalistic initiative than its French counterpart. The more politically autonomous U.S. media will produce more journalistic-initiated ("routine identical") immigration stories while the French media will produce more elite-generated ("routine habitual") immigration stories. The more commercialized U.S. media will also include more scandal stories involving immigration and sexual harassment. We will find some convergence over time as the French media become somewhat more commercialized.

Alternatively, if we attend to differences in the internal organizational structures of the French and American journalistic fields, we might expect the French press to be more sensationalist. For although there are lesser overall commercial pressures on the French media, the French national press is more centralized and concentrated than the more fragmented American journalistic field. Such direct and intense competition, coupled with a reliance on single-copy sales over subscriptions, has been identified as a major cause of more scandal-driven political coverage in the British than in the German national press (Esser 1999).

Although there is certainly some market segmentation according to class and political leanings, the major national newspapers, magazines, and television (local and cable TV are still relatively miniscule) in France compete directly for many of the same readers and advertisers, particularly in the Paris region. The daily newspapers Le Monde and Libération, for example, compete directly to attract virtually the same ideological and demographic slice of readers
(Eveno 1996: 354). In the United States, the major national newspapers, particularly the Washington Post, the Los Angeles Times and the New York Times are aware of each other and compete as a "matter of professional pride," but this competition has "little to do with business." In France, 72 percent of newspaper sales are made at kiosks on a daily basis rather than through subscriptions (and sales can vary significantly from one issue to the next), so newspapers have a strong incentive to create headlines and frame stories in a way that will entice readers to buy. In contrast, in the United States, only 19 percent of newspaper sales are "single copies" (with the remaining 81 percent due to subscriptions), which conceivably lessens the incentive to dramatize (Devillard et al. 2001: 28; Newspaper Association of America 2001). This suggests a competing field theory hypothesis:

\section{Hypothesis 2.2 (Journalistic Field Internal} Structure): Because competition in the French national journalistic field is more concentrated and intense, French media outiets will report on social issues (including sexual harassment and immigration) in more sensationalistic terms in order to attract audiences at their competitors' expense. We will find more scandals in French than in U.S. reporting on immigration and sexual harassment. Because the basic internal structure of the journalistic field in each case has not changed over time, we will not find convergence.

We now turn to consider global relations and three possible outcomes: diffusion without adoption (greater visibility of one nation-state's policies, political actors, and icons in one nation-state's media than in the other), imitation through which the dominant nation-state's media representations of social problems are increasingly echoed in the dominated nation-state, and backlash through which the dominant nationstate's media representations are increasingly less likely to appear in the dominated nationstate. Due to the United States' economic and political dominance in the world and its status

\footnotetext{
${ }^{5}$ Author interview with a managing editor of the Los Angeles Times, March 1998.
} 
as the biggest single exporter of television programs, films, music and news (SrebernyMohammadi 2000; Herman and McChesney 1997), we should expect at minimum that immigration and sexual harassment-related mentions of the United States will be much more visible in France than vice versa. Thus:

\section{Hypothesis 3.1 (Global Field Position-} Visibility Effects): In response to the increasing economic and cultural dominance of the United States across the globe, French domestic news stories on immigration and sexual harassment will be more likely to refer to the United States than vice versa.

This visibility may also translate into convergence in the content of news stories, as both social problem and field theorists suggest. For both the immigration and sexual harassment issues, there is evidence of American-dominated cross-national links among activists, policymakers and journalists since the 1970s. Political discourses about race, ethnicity, and feminism, linked to America's civil rights and women's movement and its aftermath in identity politics, have circulated widely. In France, such ideas have clearly inspired at least some immigrant and urban youth activists (Blatt 1996) and women's groups. Historians have commented that American feminists played an active role in the French women's movement, which subsequently both imitated and took pains to distinguish itself from its American counterpart (see de Pisan and Tristan 1977; Picq 1993). Interviews by one of the authors show that French feminists continued to develop ties to American feminists in the 1980s and 1990s, facilitated by the Internet, email, and cheap international telephone rates.

To the extent that visibility leads to imitation, we should thus expect French media reporting of immigration and sexual harassment to increasingly resemble that of the United States over time. That is, while French reports may generally be more likely to frame immigration in terms of social problems faced by immigrants and cultural problems caused by immigrants and U.S. reports may be more likely to emphasize discrimination against immigrants and the fiscal costs of immigration, the magnitude of these national differences should lessen over time. Likewise, while the French press may be more likely to frame sexual harassment as an abuse of professional hierarchical power and the U.S. press may be more likely to frame it as a form of sex-based discrimination in employment, the magnitude of these differences should lessen over time. We would find further evidence of positive emulation if French media references to the United States were increasingly positive over time.

\section{Hypothesis 3.2 (Global Field Position-}

Imitation): In response to the increasing economic and cultural dominance of the United States across the globe, differences in French-U.S. media framing of sexual harassment and immigration will fade over time, and the ratio of positive to negative references to the United States will increase over time.

Alternatively, domination vis-à-vis another nation-state in the global political economy could produce backlash:

Hypothesis 3.3 (Global Field PositionBacklash): In a backlash response to the increasing economic and cultural dominance of the United States across the globe, differences in French-U.S. media framing of sexual harassment and immigration will intensify over time, and, the ratio of negative to positive references to the United States will increase over time.

\section{METHODOLOGY}

This paper brings together two independentlyproduced original data sets by the authors and more than 150 interviews with French and American journalists, politicians, activists, academics and other professionals involved with the respective issues. For the case of immigration, the data set includes 750 news stories (327 U.S. and 423 French) from major American and French newspapers and television evening news broadcasts (The New York Times; the Los Angeles Times; $\mathrm{ABC}, \mathrm{NBC}$ and $\mathrm{CBS}$ evening news; Le Monde; Le Figaro; Libération; France 2 and TF 1 evening news) for those years, between 1973 and 1994, in which media attention to immigration peaked-1974, 1986 and 1994 for the United States, and 1973, 1983 and 1991 for France. "Peak media attention" years are those years during each decade in which media atten- 
tion to immigration was highest, and thus was most likely to produce a public debate providing a relatively full elaboration of the dominant ideas of the period. For the 1970s, the sample years represent the first year during that decade in which media attention rose significantly at one or more of the selected news outlets. Because media attention was generally lower during the 1970s, we included both page one and the inside-metro section page one stories on immigration for the Los Angeles Times and The New York Times; for television, we included all evening news stories from both 1974 and 1975. Because Libération appeared only sporadically in 1973 and at that time was a small alternative newspaper at the margins of the French national journalistic field, it was not included in the sample for that year.

For the U.S. sample, peak media attention years were identified by an initial search of the Los Angeles Times and New York Times indexes (immigration/emigration, aliens) and LexisNexis and the Vanderbilt Television News Archives (keywords: immig* and alien*). For the French immigration media sample, peak media attention years were identified via story counts provided by French researchers (Gastaut 1995 for Le Monde 1958-1992; Bonnafous 1991 for Libération and Le Figaro 1974-1984) and supplemented by our own manual count of complete microfiche records for Le Monde and Le Figaro (University of California, Berkeley), bound paper copies (Libération in-house library, Paris), and the exhaustive computer data base and video archive for television news at L'Institut National de l'Audiovisuel in Paris.

For each peak media attention year, only page one articles (with related inside jump articles) and stories on the main television news evening broadcasts that focused on domestic immigration (immigration to the United States, or immigration to France, respectively) in each case were coded. Stories on political refugees were not coded since these generally raise a separate set of issues than immigration strictly speaking. The Los Angeles Times, The New York Times, and U.S. television news (the three networks aggregated to be equivalent to a single media outlet) were equally weighted, as were Le Monde, Le Figaro, Libération, and French television news (the two channels aggregated), so that no single news organization would be dominant in the analyses. All proportions reported in the tables are based on these weighted averages. Complete article texts or broadcast transcripts from U.S. media outlets were obtained from the Lexis-Nexis database for available years. For years during the 1970s, for which electronic texts were unavailable, microfiche copies were obtained after consulting published newspaper indexes. For the 1974 and part of the 1986 U.S. broadcast samples, we relied on Vanderbilt Television News Archive story summaries, which provided sources interviewed and topics addressed. For the French newspaper sample, either microfiche or copies of original paper copies were coded. Where possible, French television broadcasts were viewed directly or transcripts were analyzed; otherwise we relied on descriptions provided by the INA database.

In the case of sexual harassment, we selected 685 articles published in The New York Times, Time, Newsweek, Le Monde, L'Express, or Le Nouvel Observateur from the early years of coverage (1975 for the United States, 1985 for France) through the year 2000, in which the term "sexual harassment" appeared in the heading or leading paragraphs. For this article, our analysis is limited to the 459 of these articles that were coded as actually focusing on sexual harassment (rather than simply mentioning it then focusing on another topic). To make comparisons with the data on immigration, which excluded articles that did not pertain to domestic events, most of the analyses that follow pertain exclusively to the 352 U.S. articles that focused on sexual harassment in the United States and the 55 French articles that focused on sexual harassment in France.

For those publications available on LexisNexis (i.e., The New York Times and Newsweek from 1975, Time from 1981, Le Monde from 1990), we used the "hlead" function to select those articles published during the available years that included the term "sexual harassment" or the French equivalent "harcèlement sexuel" in any of the headings or leading paragraphs. A research assistant did a manual search for Time for the years 1975-1981. We used the in-house electronic archives to search L'Express from 1987 through the end of 1998 and the Internet archives to search for the years 1999 and 2000, retaining only those articles that, like the Lexis-Nexis sample, included the term "harcèlement sexuel" in the heading or lead paragraphs. For the years after 1996, we searched the 
electronic archives of Le Nouvel Observateur for articles fulfilling our search criteria. For 1990-1996, we did a manual search, using microfilm. We searched the comprehensive archive on sexual harassment at the Association européene contre les Violences faites aux Femmes au Travail (AVFT: The European Association Against Violence Towards Women at Work) for articles published prior to 1990 in Le Monde, for articles published in L'Express before 1987, and for articles published in Le Nouvel Observateur prior to 1990.

In addition to the "core sample" of articles on sexual harassment, we also drew on additional analysis of 16 articles published in Le Monde, Le Point, or Libération in 2002. These articles constituted the entire universe of articles we could locate published in the French press between January and March 2002 on accusations of sexual harassment brought by graduate student Sandrine Bertaux against her dissertation advisor Hervé Le Bras, an influential intellectual with strong ties to the Socialist party.

For both the immigration and sexual harassment cases, coding was done at the articie lever. Each of the authors did the bulk of the coding for one of the two cases but in both cases a second coder recoded a small random sample of the articles to test for inter-coder reliability, which was 91 percent in both cases.

To evaluate Hypotheses 1.1 and 1.2 for the immigration case study, stories were coded as "1" for including any explicit mention (either by the journalist or a source) or as " 0 " for lack of any explicit mention of various problems that immigration created for immigrants, of problems created by immigrants for the rest of society, or of positive aspects of immigration. Thus many stories were coded for multiple frames. If a sub-element of a frame was found one time or multiple times the story was coded " 1 " for inclusion of the frame.

In this study, problems "for" immigrants included social problems, cultural problems, and racial/ethnic discrimination. Social frames included poor living conditions (poverty, poor housing), violations of the human rights or dignity of immigrants, personal/family problems, (non-overtly racist) crimes committed against immigrants (e.g., actions of smugglers), accidents suffered by immigrants, poor education, work conflicts, poor working conditions, or immigrant unemployment. Cultural problems for immigrants included threats to immigrants' distinctive cultures, immigrants and their children being emotionally torn between their native and their adopted cultures, or having difficulty adapting to their adopted homeland's culture (i.e., "culture shock"). Racial/ethnic discrimination frames included mentions of inferior treatment of individuals or groups due to their race or ethnicity.

Problems caused "by immigrants" were coded as cultural or fiscal. Cultural (problems caused by immigrants) frames cast immigrants' culture and religious practices as nationalist threats to the receiving country's culture. FranzOlivier Giesbert, Le Figaro's editor during the early 1990s, illustrated this negative cultural frame in a front-page essay in which he justified the need to deport illegal immigrants in order to assure the successful "assimilation" of legal North African immigrants: "We know where the utopia of 'difference' and 'multiculturalism' can end up: Lebanon"6 (Giesbert 1991). Fiscal frames included mentions of the costs posed by immigrants to social services and other government programs or the ensuing burden imposed on taxpayers. Sam Howe Verhovek (1994), reporting for The New York Times, offered a fiscal frame with this lead:

On a sultry day in July, a 25-year-old woman, Laura C., waded across the Rio Grande, slipped past the Border Patrol in Brownsville, Tex., and boarded a $\$ 49$ Southwest Airlines flight to Houston. Hoping for work and a better life, she has instead subsisted on government benefits and become one more straw threatening to break the back of America's uneasy patience with illegal immigrants.

We also coded each article for whether or not it presented immigration as a source of positive cultural diversity.

Likewise, each article on sexual harassment was coded for presence or absence of any explicit mention (again, by the journalist or a source) of specific frames. Of particular interest were frames that presented sexual harassment or a particular incident of sexual harassment as: 1) an abuse of power; 2) a form of group-based discrimination; or 3 ) an act of violence. Articles

\footnotetext{
${ }^{6}$ This and all other translations of the press articles were conducted by the authors.
} 
were coded for whether they included one or more mentions of a given frame (" 1 ") or not ("0").

A 1989 article in Le Nouvel Observateur (Gilson 1989) framed sexual harassment as an abuse of professional hierarchical power by quoting a sexual harassment victim who explained how she was overpowered by her harasser: "Why did I get into this relationship with him? I didn't have a choice. He made me wear a dress when he wanted me to wear a dress. Or pants when he wanted to see me in pants. I was afraid." A French story framed sexual harassment as part of a larger phenomenon of sex discrimination: "More often, you see a few female bosses among a lot of male bosses. The female bosses are still harassed. In France a man is still more equal than a woman. Every female boss is a secondary boss (sous-chef)" (Schifres 1985). Finally, an article published in 1999 by Le Nouvel Observateur framed sexual harassment as a form of violence by categorizing sexual harassment as one of the many "forms of violence that strike women," along with domestic violence, rape, and fernale genital mutilation (Gauthier 1999).

Several of the hypotheses made predictions about how these frames would differ over time. For the sexual harassment case, we examined three separate time periods: 1) prior to 1991 ; 2) from 1991 to 1998; and 3) from 1999 to 2000. We began the second time period in 1991 to test Hypothesis 1.2's prediction that French legislative debates, in which French lawmakers ultimately defined sexual harassment as an abuse of professional authority and as sexual violence but not as group-based discrimination, would accentuate the French-U.S. gap in framing sexual harassment as sex discrimination. We began the third time period in 1999, the first year after the culmination of Paula Jones' lawsuit against Bill Clinton, so as to be able to isolate the effect of this event in evaluating Hypotheses 2.1 and 2.2's predictions about sensationalism in reporting in both countries.

To address Hypotheses 2.1 and 2.2 for the case of immigration, we coded each article for whether it was 1 ) routine identical, 2) routine habitual, or 3) a scandal (Molotch and Lester 1974; see discussion preceding Hypothesis 2.1). As Molotch and Lester note, these categories are "ideal types" and actual events are rarely the pure expression of a single type. Whenever pos- sible we coded each event as a single type, but there were cases where it seemed inaccurate to do so. We coded each sexual harassment article for whether or not it focused on a number of specific sexual harassment scandals (e.g., Clarence Thomas' U.S. Senate confirmation hearings, the Tailhook scandal, or Paula Jones' lawsuit against Bill Clinton). To be considered a scandal, the incident had to involve a high-profile individual (e.g., national President) or institution (national military). We used an "other" category to capture any scandals that were not anticipated at the outset.

To evaluate Hypotheses 3.1-3.3, we measured the frequency of references in each national press to the other country by coding a "mirror" variable as " 0 " when, in the case of a French article, the United States was not mentioned and "1" when it was (or vice versa in the case of a U.S. article). Finally, we coded news stories for whether the references to the opposing country were positive, neutral, mixed, or negative. Unlike many of our other codes, these four are mutually exclusive.

\section{IMMJGRATION}

According to Hypothesis 1.1 (Cultural Repertoires), given the supposed dominance of "civic solidarity" themes in France, French reporting should emphasize more the problems for immigrants, as relatively underprivileged members of society, facing the challenges of a foreign culture. When the French media raise concerns about immigrants, they should discuss immigrants' failure to do enough to "fit in" with the national community. Conversely, the dominance of market-based cultural repertoires in the United States should lead the U.S. news media to emphasize the fiscal costs created by immigration for extra social services and education.

Overall, the French press is statistically more likely than the U.S. press in all three time periods to mention the social problems that immigrants faced. As is shown in Table 1, 36 percent of the 1974 U.S. sample, compared to 66 percent of the 1973 French sample, employ this "social" frame; 31 percent of the U.S. and 50 percent of the French sample include this frame in 1986 and 1983, respectively; and 25 percent of the U.S. and 50 percent of the French sam- 
Table 1. Proportion of Frames and News Event Types in U.S. and French Immigration Stories

Social Problems for Immigrants

Cultural Problems for Immigrants

Racial Discrimination

Cultural Problems Created by Immigrants

Fiscal Problems Created by Immigrants

Positive Cultural Diversity

Routine Identical

Routine Habitual

Scandal

N

Social Problems for Immigrants

Cultural Problems for Immigrants

Racial Discrimination

Cultural Problems Created by Immigrants

Fiscal Problems Created by Immigrants

Positive Cultural Diversity

Routine Identical

Routine Habitual

Scandal

$\mathrm{N}$

Social Problems for Immigrants

Cultural Problems for Immigrants

Racial Discrimination

Cultural Problems Created by Immigrants

Fiscal Problems Created by Immigrants

Positive Cultural Diversity

Routine Identical

Routine Habitual

Scandal

$\mathrm{N}$

\begin{tabular}{ccc} 
US 1974 & FR 1973 & US-FR 1970s \\
\hline 0.36 & 0.66 & $-0.30^{* *}$ \\
0.02 & 0.05 & -0.03 \\
0.06 & 0.10 & -0.04 \\
0.05 & 0.14 & -0.09 \\
0.18 & 0.08 & $0.10 \dagger$ \\
0.02 & 0.00 & 0.02 \\
0.33 & 0.28 & 0.05 \\
0.52 & 0.33 & $0.19 *$ \\
0.07 & 0.07 & 0.00 \\
42 & 65 & \\
\hline
\end{tabular}

\begin{tabular}{ccc}
\hline US 1986 & FR 1983 & US-FR 1980s \\
\hline 0.31 & 0.50 & $-0.19^{* *}$ \\
0.04 & 0.14 & $-0.10^{*}$ \\
0.18 & 0.01 & $0.17^{* * *}$ \\
0.08 & 0.32 & $-0.24^{* * *}$ \\
0.13 & 0.12 & 0.01 \\
0.08 & 0.18 & $-0.10^{*}$ \\
0.46 & 0.19 & $0.27^{* * *}$ \\
0.58 & 0.49 & 0.09 \\
0.02 & 0.05 & -0.03 \\
116 & 116 & \\
\hline
\end{tabular}

\begin{tabular}{ccc}
\cline { 2 - 3 } US 1994 & FR 1991 & US-FR 1990s \\
\cline { 2 - 3 } Delivered by 0.25 & 0.50 & $-0.25^{* * *}$ \\
Schaar (cid 5.035232$)$ & 0.06 & -0.03 \\
IP : 127.9 .11 & 0.05 & $0.06^{*}$ \\
$0.967: 04: 51$ & 0.37 & $-0.31^{* * *}$ \\
0.41 & 0.11 & $0.30^{* * *}$ \\
0.03 & 0.05 & -0.02 \\
0.39 & 0.14 & $0.25^{* * *}$ \\
0.48 & 0.59 & $-0.11^{*}$ \\
0.03 & 0.26 & $-0.23^{* * *}$ \\
169 & 242 &
\end{tabular}

Note: $\mathrm{FR}=$ France; $\mathrm{US}=$ United States.

$\dagger p<.10 ; * p<.05 ; * * p<.01 ; * * * p<.001$ (Chi-square test).

ple mention this aspect during their 1990s respective peak media attention years.

The French media also focus more on cultural problems than the American media, but the difference is most marked in the greater French emphasis on problems that immigrants' persistent cultural differences allegedly cause for society at large. Few articles in the U.S. and French samples of the 1970s (2 percent and 5 percent respectively) or 1990s samples (3 and 6 percent respectively) mention the cultural problems that immigrants face in adapting to their host society. Only during the 1980s is the French press (14 percent of stories) significantly more likely than the U.S. press (4 percent) to mention cultural problems for immigrants. In contrast, 32 percent of the 1983 French sample and 37 percent of the 1991 French sample mention cultural problems caused by immigrants, compared to only 8 percent of the 1986 and 6 percent of the 1994 U.S. samples, respectively. Five percent of the 1974 U.S. sample compared to 14 percent of the 1973 French sample focus on this dimension, but the difference is not statistically significant.

On the other hand, fiscal frames are more common in the U.S. press than in the French press in the 1970s and 1990s periods. Eighteen percent of the 1974 U.S. sample compared to 8 percent of the 1973 French sample employ this frame. In the 1990s, a full 41 percent of U.S. news stories mention this aspect versus 11 per- 
cent of French stories. (Thirteen percent of the 1986 U.S. sample and 12 percent of the 1983 French sample employ the fiscal frame.)

It seems that media reporting on immigration has indeed been shaped by national cultural repertoires related to this problem, rather than simply being a reflection of the actual reality of immigration. While the French press has discussed social problems for immigrants more than the U.S. press, there is no evidence that living conditions for immigrants (nor even for second-generation immigrant youth) are worse in France as compared to the U.S. (see Dubet 1989). In fact, given the highly precarious position of America's working poor, conditions for immigrants may be worse in the United States, where, between the 1960s and the 1990s, immigrants were likely to have less education, to earn less relative to native residents, and to suffer from more precarious working conditions (Portes and Rumbaut 1996:57-92). Likewise, despite a greater French focus on problems associated with cultural integration, the available evidence suggests that during the 1970s through the 1990s both French and American immigrant populations were following historic patterns of gradual assimilation (Neiriel 1996; Hargreaves 1995; Tribalat 1995; Portes and Rumbaut 1996).

Neither is there any evidence that the greater U.S. media focus on fiscal costs of immigration reflects a larger objective fiscal burden of immigration in the United States as compared to France. In fact, given the far more generous French welfare state, French expenditures for immigrants have been at least as extensive as those offered to immigrants in the United States. One could argue that the U.S. press has focused relatively more on fiscal costs because immigration (both legal and illegal) has continued at high rates in the United States since the 1970s, creating greater concerns about resources there; while slower flows of immigrants to France have turned the national conversation to questions of integration and social cohesion. Yet, even if it has been reduced, French immigration — legal and illegal — has never really ceased, and French foreign-born population and levels of immigration were quite comparable to that of the United States during the period in our study. Moreover, if heavy, recent immigration alone were a key factor, then fiscal frames should be more common in the French media of the early 1970s, but they are not. Finally, in the United States, welfare abuse is an issue that goes well beyond immigrants, recent or otherwise; the charge is leveled at least as often against African-Americans, most of whom are not recent immigrants to say the least (Gilens 1999; Gans 1995).

Thus, it does appear that national cultural repertoires shape the public framing of social problems. However, the relative frequency of the frames varies from one decade to the next, and cross-national differences are not always statistically significant, suggesting that other factors are at work.

Hypothesis 1.2 (Institutional-Law) attempted to restore attention to contingent historical processes, particularly the powerful effects of legal regimes. French media reporting of cultural aspects of immigration generally supports Hypothesis 1.2. Consistent with changes in government policies, cultural problems of immigration emerged as a major frame in the French media during the early 1980s. As Table 1 shows, during 1983 when the Mitterrand government wras promoting cultural diversity policies, 18 percent of our French sample frame immigration as a positive cultural diversity issue, up from 0 percent in 1973. In 1983, mentions of cultural problems for immigrants also increase from 5 percent of our sample in 1973 to 14 percent. The increasingly contested nature of these policies, however, is evident in the relatively high prevalence of mentions of cultural problems caused by immigrants in our sample: increasing from 14 percent of stories in 1973 to 32 percent in $1983 .^{7}$ By 1991, reflecting the new policy consensus that integration rather than multiculturalism is desirable, positive cultural diversity frames drop from 18 to 5 percent, while concern with problems caused by immigrants' cultural differences remains high (37 percent in 1991, compared to 32 percent in 1983).

Patterns of fiscal framing also support Hypothesis 1.2. The U.S. media in 1974 are more likely, at 18 percent, to employ this frame

${ }^{7}$ It should be emphasized here that the presence of a frame does not connote a clear position, only that the issue has been raised. Many of the French stories of 1983 noted Le Pen's attacks on immigrants' cultural differences only in order to critique his position. 
than the French media in 1973, at eight percent. There is no statistically significant difference in the frequency of the fiscal frame in the 1986 U.S. or 1983 French media samples, which are at 13 and 12 percent, respectively. Only in the 1994 U.S. sample, after immigrants' use of welfare has become the focus of political action and policy formation, do more than 40 percent of the U.S. sample employ a fiscal framing, compared to 11 percent of the 1991 French sample.

Hypothesis 1.2 predicted that the racial discrimination frame will be employed more in the U.S. media sample relative to the French media sample. Indeed, the discrimination frame is significantly more likely in the U.S. press than in the French press during both the 1980s and 1990 s peak media attention years (18 percent of 1986 U.S. news stories versus 1 percent of 1983 French stories; and 11 percent of 1994 U.S. news stories versus 5 percent of 1991 French news stories). During the 1970s sample years, racial discrimination frames are mentioned in 6 percent of U.S. stories versus 10 percent of French stories, but the difference is not statistically significant. In 1972, just prior to the period from which these news stories are drawn, the French government passed an antiracism law. This legal reform-by bringing racial discrimination to the attention of the French public — might be partly responsible for the higher use of this frame in the French media in 1973 compared to the later periods. However, when in subsequent years efforts to reduce systematic discrimination were stymied by the French official refusal to gather data by race, the term largely disappears from news discourse. ${ }^{8}$

Because the U.S. journalistic field is more dependent on the market and less dependent on the state, Hypothesis 2.1 predicted that the U.S. media would be more sensationalist while demonstrating greater independent initiative,

\footnotetext{
${ }^{8}$ Note that "immigration" serves to a certain extent as "code" for "race" in France, whereas immigration in the United States does not encompass the important "racial" element of black-white relations. This difference - that our U.S. case does not include an important related issue (black-white relations) in which discrimination is most likely to be discussed, whereas our French case does (race being synonymous with the immigration issue) — only makes our findings more robust.
}

compared to the French media. Hypothesis 2.1 further posited that the French media would feature more (elite-generated) routine habitual stories.

Hypothesis 2.1 receives mixed support from the data. As is shown in Table 1 and consistent with expectations, routine identical stories are significantly more likely in the U.S. than in the French media in 1983/86 and 1991/94 (46 versus 19 percent, and 39 versus 14 percent, respectively). In the 1973/74 comparison, 33 percent in the U.S. media sample versus 28 percent of French stories are routine identical, a difference that is not statistically significant.

Many U.S. routine identical stories could be termed "investigative journalism" and offer indepth, critical examinations of the office-holders and government agencies dealing with immigration. For example, in 1994 The New York Times published a five-part investigative series on the U.S. Immigration and Naturalization Service, with such headlines as "In Immigration Labyrinth, Corruption Comes Easily" (Engelberg 1994) and "Insider's view of the INS: Cold, Rude and Insensitive"" (Sontag and Engelberg 1994). That same year, a Los Angeles Times article independently assessed the effectiveness of U.S. legislation sponsored by Senator Barbara Boxer to stop illegal immigrants by placing National Guard troops along the Mexican border.

What sets these stories apart is not their critical tone. When French politicians made racist or insensitive remarks, French journalists did not hesitate to say so, as with one Le Monde story headlined simply "Too much" [Trop] (Frappat 1991). At other times, the truth or falsity of officials' claims were assessed, and found wanting, as with another Le Monde article (Normand 1991) headlined in part "The bad accounts of the Paris mayor" ("... les mauvais comptes du maire de Paris"). The difference is that relatively more American stories were published because of journalist initiative, rather than as reactions to the day's actions of political elites.

On the other hand, contrary to our expectations, French news stories are not systematically more likely to be "routine habitual," or generated by the actions of political elites. In the 1970s comparison, routine habitual stories are actually significantly more common in the U.S. media (52 percent compared to 33 percent in France). In the 1980 s, the gap (58 percent in the 
U.S. media, 49 percent in the French media) is not statistically significant. Only in the 1990s is the French press significantly more likely than that of the United States (59 percent to 48 percent) to feature routine habitual stories. Nor is the U.S. press shown to be systematically more sensationalistic, as measured by proportion of scandal stories. Scandals (7 percent of both nations' coverage in 1973 and 1974 and 2 and 5 percent of coverage in the U.S. and France respectively in 1986 and 1983) are equally rare in the 1973/74 and 1983/6 comparisons; in 1994 the U.S. media are actually significantly less likely to publish scandal stories than the French press in 1991 (3 percent compared to 26 percent). French scandal stories that year included controversies surrounding anti-immigration rhetoric of several leading politicians (Jacques Chirac, Edith Cresson, Valéry Giscard d'Estaing, and Jean-Marie Le Pen), which were brought to light by other politicians or associations who criticized, amplified, and in some cases re-framed the meaning of the original remarks.

Despite the increasing commercialization of the French press, there is no clear convergence between U.S. and French event generation between the 1970s and 1990s. In fact, the respective gaps in the American and French media's tendency to report scandals and routine identical stories is wider among the sampled articles in the 1990s than in the 1970s. In sum, overall relation of the journalistic field to the state and market, as emphasized by Hypothesis 2.1 , can only be unequivocally related to our finding that routine identical (journalist-initiated) stories are more likely to appear in the relatively more politically autonomous U.S. press compared to the more state-dependent French press.

The immigration case provides more support for Hypothesis 2.2, which predicted that a concentrated, centralized national journalistic field would make French news reporting of immigration more sensationalistic than U.S. reporting. In 1991, the only year when there is a statistically significant difference in the national proportions of scandals, such reporting appears most frequently in the French news media ( 26 percent versus 3 percent).

The immigration data strongly supports Hypothesis 3.1 (global field position-visibility effects), which predicted that French domes- tic news stories would be more likely to refer to the United States when reporting on immigration than vice versa, due to the increasing economic and cultural dominance of the United States across the globe. In 1986, 2 percent of the U.S. sample versus 7 percent of the French sample mention the opposing country. The two U.S. stories mentioning France are a New York Times article in which the Population Council's Charles Keely notes that a lower proportion of Americans than French is foreign born ( 7 percent versus a somewhat inflated 11 percent) (Reinhold 1986), and a July 3, 1986 ABC News story on the Statue of Liberty's Centennial celebration which comments on American "ignorance about France's role" in the statue's history (both coded "neutral"). During the 1990s, none of the U.S. stories mention France, but 16 percent of French news stories mention the United States. (In 1973, only 6 percent of French stories mention the United States, a percentage that is not significantly different from the 0 percent of the 1974 U.S. sample.) Conceivably, we would have found even greater U.S. focus on the part of the French media if we had also examined French reporting during U.S. peak media attention years (1974, 1986 and 1994).

Hypothesis 3.2 predicted that the growing economic, political, and cultural power of the United States would lead to growing similarities in how the French and U.S. media frame immigration, while Hypothesis 3.3 predicted that there would be a backlash in response to growing U.S. power, resulting in more dissimilar media framing of this problem. Likewise, whereas Hypothesis 3.2 predicted that the French media would report on the United States in an increasingly positive way, Hypothesis 3.3 predicted that French reporting on the United States would be more negative over time.

Our analysis provides tentative support for Hypothesis 3.3. The gap in the proportion of American and French articles framing immigration as either creating cultural problems or as creating fiscal problems (Table 1) is large and statistically significant in the 1991/1994 period; this is not the case in the two earlier periods for the fiscal frame or in 1973/1974 for the cultural problems created by immigrants frame. In the 1991/1994 comparison, there is also a relatively large and statistically significant gap in the frequency of U.S. and French media discussing "social" problems for immigration 
frames. While the pattern of increasing difference in framing does not hold for all of the immigration frames, for none of the frames does there appear to be increasing similarity in framing.

On the other hand, we do not find evidence that the tone of French reporting on the United States becomes increasingly negative over time. For all three comparison periods, there is a mix of negative and positive mentions, with a slightly higher proportion of positive mentions only in the middle period. As shown in Table 2, in 1973, two French articles discuss the United States in a negative and one in a positive light. In 1983 and 1991, the ratios of negative to positive mentions of the United States are 3:4 and 13:9, respectively. In a 1983 interview in Libération, the French intellectual André Bercoff (using the pseudonym Caton) waxed eloquent about the "formidable energy of rising minorities" in the United States" (Caton 1983). At other times, positive references are implicit, as in the Libération headline announcing the "beur" (second-generation North African immigrant ) march for equality's arrival in Paris: "Beur is beautiful" (Favereau 1983). Less posci itive assessments, however, are also commoñ. In a 1983 Le Monde article, Michel TibonCornillot, a social scientist at the Ecole des Hautes Etudes en Sciences Sociales offered an early comparison of a "French model" and an "American model" of immigration. The American and French models represent two "opposing poles" of approaches to the integration of immigrants, he wrote. For the French model, "an explicit discourse about difference is not possible, even if practices do differ. Foreigners wishing to become French are thus asked to give up any public demand to have their differences recognized, in exchange for joining in a unified whole. On the other hand, they are not being asked to abandon their customs, but it is up to them to maintain them" (Tibon-Cornillot 1983).

Likewise, in 1991, references to the United States ran the gamut from positive to negative. Martin Luther King served, as he did in 1983, as a positive reference for immigrant youths seeking social justice (e.g., Bernard 1991). In another case, an attempt by a leading conservative politician to score political points by warning of an imminent "invasion" of immigrants was evidently U.S.-inspired: UDF party leader and former president Valéry Giscard d'Estaing claims he got the term "invasion" from a Time magazine cover (Le Figaro 1991). More frequently, references to the U.S. model arecoatchwords or slogans-ghetto, Bronx, or "multiculturalisme" - and in such cases the implication is usually negative. At Le Monde, social issues editor Robert Solé often sprinkled his essays with negative references to the American model. In one article, he wrote: "Even activists for integration have become discouraged. They ask themselves whether the famous "French model" is solid enough. Have we

Table 2. Foreign Mention in U.S. and French Immigration Stories

Proportion of Domestic-focused Stories Mentioning Other Country Ratio of Negative to Positive Mentions N

Proportion of Domestic-focused Stories Mentioning Other Country Ratio of Negative to Positive Mentions N

Proportion of Domestic-focused Stories Mentioning Other Country Ratio of Negative to Positive Mentions N

\begin{tabular}{ccc} 
US & FR & US-FR \\
1974 & 1973 & $1970 \mathrm{~s}$ \\
\hline 0.00 & 0.06 & -0.06 \\
- & $2: 1$ & - \\
42 & 65 & \\
\hline $\mathrm{US}$ & $\mathrm{FR}$ & $\mathrm{US}-\mathrm{FR}$ \\
1986 & 1983 & $1980 \mathrm{~s}$ \\
\hline 0.02 & 0.07 & $-0.05 \dagger$ \\
\hline- & $3: 4$ & - \\
116 & 116 & \\
\hline $\mathrm{US}$ & $\mathrm{FR}$ & $\mathrm{US}-\mathrm{FR}$ \\
1994 & 1991 & $1990 \mathrm{~s}$ \\
\hline 0.00 & 0.16 & $-0.16^{* * *}$ \\
\hline- & $13: 9$ & - \\
\hline 169 & 242 &
\end{tabular}

Note: $\mathrm{FR}=$ France; US $=$ United States.

$\dagger p<.10 ; * p<.05 ; * * p<.01 ; * * * p<.001$ (Chi-square test). 
already become an ethnically-compartmentalized society, à l'américaine?" (Solé 1991). In a Le Figaro article, editorial board member Alain Peyrefitte wrote: "American society has ceased to be shaped by its melting-pot. Under the name of a multicultural or multi-ethnic society, the reality is now a ferocious segregation, a juxtaposition of ghettos." U.S. mentions in Libération include a full-page interview with the socialist government cabinet minister JeanLouis Bianco who commented "Our society isn't constructed on a base of ethnic origins ... we aren't the United States" (Colson and FauvetMycia 1991), a story about urban riots quoting a legislator (deputé) urging government action so that "our banlieues [poor suburbs - analogous to American "inner-cities"] don't become the new Bronx" (Pandraud 1991), and a piece warning of the "menace" of a "ghettoization" of French society "moving a secular and republican France closer to that American example, long denounced and now dreaded" (Mir 1991).

\section{SEXUAL HARASSMENT}

Data analysis supports Hypothesis 1.1 (cultural repertoires), which predicted that the French media would be more likely to frame sexual harassment as an abuse of professional/economic power, while the U.S. media would be more likely to frame it as a form of sex-based discrimination in employment. As Table 3 shows, 24 percent of the U.S. sexual harassment stories compared to 67 percent of the French articles frame sexual harassment as an abuse of power. Twenty-three percent of the U.S. articles frame sexual harassment as a form of sex-based discrimination in employment, compared to 11 percent of the French articles.

Predicting the influence of legal definitions on media framing, Hypothesis 1.2 also posited that the French media would favor framing sexual harassment as an abuse of professional power, while the U.S. media would rely more on discrimination frames. Additionally, this hypothesis predicted that the French media would be more likely to frame sexual harassment as an act

\section{Delivered by Ingenta to}

Schaar (cid 54005232)

Table 3. Proportion of Frames and Focus on Scandal in U.S. and French Sexual Harassment Stories

\begin{tabular}{|c|c|c|c|}
\hline & US 1975-2000 & Fr 1985-2000 & US-Fr \\
\hline Power & 0.24 & 0.67 & $-0.43 * * *$ \\
\hline Discrimination & 0.23 & 0.11 & $0.12 *$ \\
\hline Violence & 0.12 & 0.33 & $-0.21 * * *$ \\
\hline Scandal & 0.30 & 0.09 & $0.21 * *$ \\
\hline \multirow[t]{2}{*}{$\mathrm{N}$} & 353 & 55 & \\
\hline & US pre 1991 & FR pre 1991 & US-FR pre 1991 \\
\hline Power & 0.19 & 1.00 & $-0.81 * * *$ \\
\hline Discrimination & 0.35 & 0.43 & -0.08 \\
\hline Violence & 0.09 & 0.57 & $-0.48 * *$ \\
\hline Scandal & 0.00 & 0.00 & 0.00 \\
\hline \multirow[t]{2}{*}{$\mathrm{N}$} & 43 & 7 & \\
\hline & US 1991-98 & FR 1991-98 & US-FR 1991-98 \\
\hline Power & 0.26 & 0.59 & $-0.33 * *$ \\
\hline Discrimination & 0.21 & 0.07 & $0.14 \dagger$ \\
\hline Violence & 0.13 & 0.28 & $-0.15^{*}$ \\
\hline Scandal & 0.38 & 0.17 & $0.21 \dagger$ \\
\hline \multirow[t]{2}{*}{$\mathrm{N}$} & 281 & 29 & \\
\hline & US 1999-2000 & FR 1999-2000 & US-FR 1999-2000 \\
\hline Power & 0.10 & 0.53 & $-0.43 * *$ \\
\hline Discrimination & 0.31 & 0.05 & $0.26^{*}$ \\
\hline Violence & 0.10 & 0.32 & $-0.22 \dagger$ \\
\hline Scandal & 0.00 & 0.00 & 0.00 \\
\hline $\mathrm{N}$ & 29 & 19 & \\
\hline
\end{tabular}

Note: $\mathrm{FR}=$ France; US $=$ United States.

$\dagger p<.10 ; * p<.05 ; * * p<.01 ; * * * p<.001$ (Chi-square test). 
of violence, consistent with French legal definitions. Indeed, 33 percent of French articles frame sexual harassment as a form of interpersonal violence, compared to 12 percent of U.S. domestic news coverage. There is no evidence that sexual harassment is inherently more discriminatory in the United States or involves a greater abuse of power or is more violent in France. Rather, it seems that differences in national cultural repertoires and legal definitions make the U.S. and French media more likely to frame it in those respective ways.

Hypothesis 1.2 predicted that the tendency of the French press to frame sexual harassment as an abuse of professional power and as an act of violence and the U.S. tendency to frame it as a form of sex-based discrimination in employment would be most pronounced after 1991. Table 3 gives the proportions of these frames separately for three different time periods: 1) prior to $1991 ;{ }^{9}$ 2) from 1991 to 1998 ; and 3) from 1999-2000. The data on the discrimination frame provides the strongest support for this prediction. Prior to 1991, when the French Parliament debated and passed two sexual harassment statutes defining sexual harassment as an abuse of professional authority and an act of sexual violence but not as gender discrimination, the U.S. press is not significantly more likely at 35 percent than the French press at 43 percent to frame sexual harassment as a form of sex-based discrimination in employment. After 1991, however, the U.S. media is significantly more likely to employ this frame than the French media. In 1991-1998, 21 percent of the U.S. sample, compared to 7 percent of the French sample, frames sexual harassment as a form of sex-based discrimination in employment; in 1999-2000, 31 percent of the U.S. compared to 5 percent of the French sample employs this frame.

The data, however, do not support Hypothesis 1.2 's predictions that the relatively greater French media's tendency to frame sexual harassment as an issue of power and of violence would be greater from 1991 onward, after the debate and passage of the new French law. The FrenchU.S. gap from 1991 onward for these two frames

\footnotetext{
${ }^{9}$ Caution should be used in interpreting the French data for the earliest period, since the sample size for that period was extremely small.
}

is wide but not as large or as statistically significant as that for the pre-1991 period. Between 1991 and 1998, 59 percent of French articles frame sexual harassment as an abuse of power compared to 26 percent of U.S. articles, and in 1999-2000, 53 percent of the French compared to 10 percent of the U.S. sample employ this frame. However, prior to 1991, all of the French articles frame sexual harassment as an abuse of professional hierarchical power, compared to only 19 percent of U.S. articles.

Likewise the French media are more likely than the U.S. media to frame sexual harassment as a form of violence during all three periods but this pattern is most pronounced before 1991. In 1991-1998, 13 percent of the U.S. and 28 percent of the French articles frame sexual harassment as an act of violence, and in 1999-2000, 10 percent of the U.S. compared to 32 percent of the French sample use this frame. However, prior to 1991, 57 percent of the French articles frame sexual harassment as a form of violence, compared to 9 percent of the U.S. articles. This suggests that the violence and power frames were already readily accessible in the French context before they were institutionalized into law. It may also indicate that the greatest effect of a new law is not to amplify pre-existing frames but to help discredit emergent frames with weaker roots in national cultural repertoires.

Hypothesis 2.1 predicted that, because the American journalistic field is more marketdominated and the French journalistic field is more state-dominated, the U.S. media would be more likely to report on sexual harassment scandals involving high-profile individuals or institutions than the French media, but that there would be some convergence over time as the French media become somewhat more commercialized. In contrast, Hypothesis 2.2 predicted that, because competition in the French national journalistic field is more concentrated and intense, we would see more scandals involving high-profile individuals or institutions in French compared to U.S. reporting on sexual harassment. Table 3 gives the proportion of U.S. and French articles that focus on sexual harassment scandals involving high-profile individuals or institutions. The data provides strong partial support for Hypothesis 2.1 and no support for Hypothesis 2.2. Thirty percent of the U.S. sample, or 106 articles, focus on sexual 
harassment scandals, compared to only 9 percent (five articles) of the French sample, but we find no evidence of convergence over time.

Among the U.S. scandals, Anita Hill's accusations against Clarence Thomas (15 percent of all articles) and Paula Jones' accusations against Bill Clinton (10 percent of all articles) are featured most prominently. Only five French articles can be categorized as sexual harassment scandals. Two of these articles reported on criminal charges of rape, assault, and sexual harassment brought against Toulon's National Front Assistant Mayor of Housing (an elected position). Other articles coded as scandals include one 240-word article in Le Monde reporting on the 1992 resignation of small-town Mayor Claude Fontes following sexual harassment accusations, and a short piece in Le Monde and a single article in Le Nouvel Observateur recounting the 1998 Labor court hearing concerning accusations by a municipal employee that he had suffered from job retaliation after having been sexually harassed by the (openly gay) Mayor of Pau, André Labarrère.

Table 3 also provides the frequencies of reports on scandals over time. Contrary to Hypothesis 2.1's prediction that the rate at which the U.S. and French media report on sexual harassment scandals would converge over time, as the French media became somewhat more commercialized, Table 3 shows that all of the scandals in both countries occur in the middle period. During 1991-1998, the U.S. media are significantly more likely, at 38 percent (106 stories), to include such articles than their French counterparts at 17 percent ( 5 stories).

While the core data set, which ends in 2000, does not suggest that French reporting on sexual harassment is becoming more sensationalist over time, additional media analysis in 2002 provides tentative evidence that it is. Following the distribution to several media outlets of an anonymous package containing a graduate student's charges of sexual harassment against her dissertation advisor, at least 16 articles on the student's accusations were published in leading French newspapers and newsmagazines during the first three months of 2002. Although it did not reach the proportions of reporting on Clarence Thomas' Senate hearings or the Clinton scandals, this scandal was much bigger than any to date and was labeled by Le Monde ombudsman Robert Solé (2002) a "first of its kind." The fact that the professor in question, Hervé Le Bras, was an influential intellectual with strong ties to the Socialist party also contributed to the sensationalism of this story (see Saguy 2003).

Did this scandal erupt in 2002 due to increased commercialization of the French press? Although this may have played a role, state regulation of the media seems to provide a better explanation for this shift. Until 2001, French law prohibited the mass media from reporting on criminal charges accompanied by civil claims ${ }^{10}$ before the prosecutor decided whether or not to pursue the case. In February 2001, the Cour de Cassation (French High Court) overturned this law, ${ }^{11}$ which made it legally possible to report on the Le Bras case in 2002. Before 2001, such reporting would have been illegal under French law. The eruption of the Le Bras scandal in 2002 suggests that the law banning reporting on criminal accusations before a court ruling, which was overturned in February 2001, was crucial in limiting coverage of sexual harassment accusations between 1985 aria 2000. Previous work, showing that American sexual harassment scandals have gotten considerable press in France between 1991 and 1998 (Saguy 2002), further suggests that the French press is not above writing about scandals that don't carry the risk of a lawsuit. In other words, between the state and market - both of which Hypothesis 2.1 predicted would constrain reporting - the level and kind of state constraints on reporting seem to have played a greater role in suppressing coverage of domestic sexual harassment scandals prior to $2001 .^{12}$

${ }^{10}$ This is a common procedure in French law but is not possible in the U.S., where criminal and civil charges must be pursued independently.

${ }^{11}$ Arrêt no 810 du 20 février 2001, Cour de Cassation-Chambre criminelle.

12 In November 2004, Berteaux's case against Le Bras was dismissed following a criminal investigation. In a note following its story on the dismissal, Le Monde, which had been harshly criticized for violating Le Bras' "private life," apologized for having reported on the accusations almost three years prior: "Issues of mores, which often come down to a question of 'she said he said', demand particular caution" (Zappi 2004). It remains to be seen whether French reporting on sexual harassment charges will be con- 
Table 4. Foreign Mention in U.S. and French Sexual Harassment Stories

\begin{tabular}{|c|c|c|c|}
\hline \multirow{4}{*}{$\begin{array}{l}\text { Proportion of Domestic-focused Stories Mentioning Other Country } \\
\text { N }\end{array}$} & $\begin{array}{c}\text { US } \\
1975-2000\end{array}$ & $\begin{array}{c}\text { FR } \\
1985-2000\end{array}$ & US-FR \\
\hline & 0.00 & 0.25 & $-0.25 * * *$ \\
\hline & 353 & 55 & \\
\hline & FR pre 1991 & FR 1991-98 & FR 1999-2000 \\
\hline $\begin{array}{l}\text { Ratio of Negative to Positive Mentions among French Sexual } \\
\text { Harassment Stories Mentioning the U.S. }\end{array}$ & $1: 1$ & $7: 0$ & $3: 0$ \\
\hline
\end{tabular}

Note: $\mathrm{FR}=$ France; $\mathrm{US}=$ United States.

$* p<.05 ; * * p<.01 ; * * * p<.001$ (Chi-square test).

One might argue that U.S. reporting on sexual harassment is actually more scandalous, in that there have been more accusations leveled there against prominent U.S. government officials. This makes intuitive sense, given that U.S. sexual harassment jurisprudence does more to empower sexual harassment victims in bringing charges than do French laws (Saguy 2003). That said, we would argue that the sexual harassment accusations leveled at two Mayors and one Assistant Mayor during the 1990s would have provided sufficient material for Boandal if the French media had been so inclined. Yet these three accusations generated a mere five articles in the three French publications surveyed. Moreover, the French press showed much more interest in reporting on a graduate student's sexual harassment case against her high-profile professor after legislative reform made it legal to report on pending court cases, suggesting that such state controls previously had a deterrent effect on sexual harassment scandals.

The fact that U.S. sexual harassment scandals often take the form of traditional sex scandals, despite the fact that American feminist legal scholars have taken pains to distinguish the issue of sexual harassment as a form of workplace discrimination from questions of sexual morality, may also make them more likely in the United States and less so in France, as there is a general lesser prevalence of "sex scandals" in the French media (Thompson 2000: 10; Castells 1997: 324). This may also partly explain why we find the French media more sensationalist when it comes to immigration than to sexual harassment and reminds us that national news report-

strained by such attitudes in the future, now that journalists have the legal right to cover them. ing can be more or less sensationalist depending on the issue.

Hypothesis 3.1's prediction, that the United States would be more visible in the French press than vice versa, is supported by the data. As with reporting on immigration, French reports on sexual harassment are more likely to mention the United States than vice versa. As is shown in Table 4, none of the U.S. stories mention sexual harassment in France, while 25 percent of the French stories mention the American case.

Ing The evidence for Hypothesis 3.3 (Global rieid Position-Backlash) and Hypothesis 3.2 (Global Field Position-Imitation) is mixed. The gap in prevalence of the discrimination frame in our U.S. and French media samples does grow over time, from 8 percentage points to 14 points to 26 points, as Hypothesis 3.3 predicted. However, the national difference in the power frame is highest in the earliest period (81 percentage points), dropping down in 1991-1998 (33 percentage points), and increasing again but not to the pre 1991 level in 1999-2000 (43 percentage points). The national gap in use of the violence frame shows a similar pattern, moving from 48 percentage points to 15 points to 22 points over the three time periods.

Hypothesis 3.2 predicted that the ratio of positive to negative references to the United States would grow over time, while Hypothesis 3.3 predicted the opposite pattern. These hypotheses are difficult to test with the sexual harassment data because there is very little variation on the dependent variable. Unlike in the immigration case, where there is a mix of positive and negative references to the United States, the overwhelming majority of references to the United States are negative in the case of sexual harassment. Only in the first period is 
there one positive mention of the United States. The article in question, published in the Le Nouvel Observateur (Rivaud 1990) mentioned with a tone of admiration that, in the United States, "a former sexual harassment victim created a specialized consulting firm. Her clients: employers as well as employees."

All of the other references to the United States are negative. In the 1991-1998 period, there are 7 negative references to the United States; the corresponding figure for the 1999-2000 period is 3. The following excerpt from a 1992 article in Le Monde (Bobin 1992) is representative of how the French media portray the United States. Describing the sexual harassment statute just added to the Labor Code, it noted that Secretary of Women's Rights Véronique Neiertz wanted to present a "pragmatic and modest" law and was concerned "not to fall into excesses characteristic of the American situation that ends up repressing all relations of seduction between men and women."

A 1995 article in L'Express whose title translates as "In France, You Need Proof" (Sarañgá 1995) clearly refered to the United States as a place where proof of sexual harassment is not necessary to win thousands of dollars in a sexual harassment lawsuit. After noting that a successful French plaintiff was awarded a mere 5,000 Francs (about \$800) in compensatory damages for an egregious case of sexual harassment, the journalist wrote that in France, "we are far from the thousands of dollars pocketed by American women." A politician accused of sexual harassment in 1998 was quoted by Le Monde as saying he feared his accuser was "the French Paula Jones" (Le Monde staff writer 1998). The fact that 1991-1998 is dominated by a series of high profile American sexual harassment scandals, which were regarded as overblown in France (see Saguy 2003), probably contributed to both the high visibility and negative image of the United States in France during this period.

Finally, independent of any of our specific hypotheses, the joint examination of media reporting of both immigration and sexual harassment further suggests that the media framing of immigration and related issues of multiculturalism informed reporting on sexual harassment. On more than one occasion, the French press framed feminism as one instance of a larger "politically correct" movement, grouped together with anti-racist initiatives like affirmative action and multiculturalism. This pattern can be seen most clearly when examining French reporting on sexual harassment in the United States. For instance, the title of a 1995 L'Express article (Coste 1995), which translates as "Sexually Correct America," and a 1997 article in Le Nouvel Observateur (Giroud 1997) that would be translated as "Sexually incorrect?," both reporting on American excesses in sexual harassment regulation, played with that familiar connection. Similarly, the contrast between "French" integration and "American" multiculturalism and ethnic strife seem to echo the contrast between "French" gender harmony and "American" gender conflict in articles like the following:

American feminism has flourished in an environment completely different from ours. .. . What seems to us to be a game, a sweetness of life, even the expression of nature, to them is perceived as a threat to equality! We don't want the separation of the sexes [emphasis added] (Badinter 1994).

In other words, French media/political discourse about sexual harassment and gender relations borrorns directly from previous discussions of racial strife and ethnic separatism and only makes sense in this context. Indeed, some French scholars have drawn a direct link between the negative references to American multiculturalism embedded in immigration reporting and the subsequent journalistic and intellectual disdain toward American-style approaches to sexual harassment. In the words of Eric Fassin (1999:232): "The language of ethnicity (from differentialism to 'communautarisme') becomes the language used to reflect on a variety of other problems. ... it provides a lexicon with which to approach both gender and sexuality."

\section{CONCLUSION}

Given arguments about increasing cultural globalization, our goal has been to better explain when and how the content and form of national media debates about immigration and sexual harassment issues will converge or diverge. In general, we find scant evidence of increasing convergence in news content and form from the 1970s through the end of the 20th century. Rather, we find that the French and American 
mediated debates on these issues tend to differ systematically and in ways that seem to reflect national cultural differences. However, we also find historical variation that cannot be adequately explained by reference to broad cultural repertoires and for which national laws provide greater explanatory power. Future research should further examine how culture is embedded in legal and other institutions and how variation in institutions contributes to competing cultural frameworks, drawing on a range of other cross-national and over-time comparisons.

Of the two broad shaping forces on journalistic production - the market and the statestate regulations and laws seem to play a more consistent role in shaping substantive media reporting on sexual harassment and immigration. In France, once laws permitting reporting on pending court cases were enacted, the press began to cover domestic sexual harassment scandals more aggressively. Perhaps due to broadly written libel laws and restrictions on press access to government documents, French immigration coverage seems less likely than that of the American media to include investigative reporting on the inner workings of gevernment bureaucracies. We also find tentative evidence that the internal structure of competition within the journalistic field shapes news coverage. For the immigration issue especially, the more centralized and intensely competitive French media field produced somewhat more scandal stories.

Scholars should further develop this line of inquiry by examining reporting on these or other social problems in other countries and time periods, which will provide greater variance in the market and state controls over journalism. Future work should examine the effect that field relations have not only on the form (e.g., news genre) of news reporting but on the content (e.g., frames) as well. In addition, research should examine how, in media debates of a given topic, the diversity of total frames evoked and sources cited vary depending on the extent of state or market domination of the journalistic field. Future work could also develop other indicators to measure such underlying phenomena as ideological emphasis, journalistic independent initiative, and sensationalism.

Our analysis highlights broad cross-national differences in press treatment. Yet differences also exist among national media outlets, differences which - in the context of competitive dynamics of distinction - provide another contextual element that can be used to further strengthen the explanatory power of a comparative field analysis. This kind of analysis could examine how issue frames and story types differ systematically across types of media outlets, the mechanisms by which journalists come to imitate or distinguish themselves from their colleagues and competitors, and ultimately the ways in which this process serves to shape public debate.

By collecting data over a longer time period and for several different social problems, future work could better examine the use of antiAmerican rhetoric in French domestic power struggles over time. Under what conditions is such rhetoric most likely to be employed or to be effective? Can we identify general traits of social/political issues that make them more susceptible to either imitation or backlash? What role have contingent historical events played in breaking with previous issue framings? Researchers should also examine the use of anti-American rhetoric in countries other than France. Which sorts of countries are most likely to employ such rhetoric and how do they vary in how they do so?

Whether or not globalization is leading to cultural convergence is highly contested. Although this article tends to highlight difference, and to a certain extent backlash, rather than convergence, it does not simply contribute further evidence for the naysayers in the great globalization debate. Rather, we have sought to go beyond the "yes or no" convergence question to examine more closely how, when, and why cross-national similarities or differences are created, maintained or contested. In this spirit, we offer a model that can be generalized beyond the United States and France to specify the relevant cultural and institutional factors that produce domestic "social problems" discourses in an increasingly global cultural environment. These include: 1) dominant national cultural repertoires; 2) relevant laws and regulations; 3 ) internal dynamics and structural position of the journalistic field that is producing social problem discourses, and 4) position in the global field of nation-states. Far from providing the last word, we hope to inspire further crossnational studies oriented toward identifying pat- 
terns, structures, and relations embedded in complex - but not unexplainable-global-local processes of meaning construction.

Rodney Benson is Assistant Professor in the Department of Culture and Communication at New York University. He is currently finishing a book that examines immigration news coverage in the United States and France to shed light on how the US and French national journalistic fields shape public political debate. He is the editor, with Erik Neveu, of Bourdieu and the Journalistic Field (Polity 2005), which demonstrates how field theory can be used for media research and features new translations of Pierre Bourdieu and French colleagues.

Abigail C. Saguy is Assistant Professor of Sociology at University of California Los Angeles. In her 2003 book, What is Sexual Harassment? From Capitol Hill to the Sorbonne (California), she demonstrates how political, legal, and cultural traditions in the United States and France have provided distinct avenues for social actors, resulting in different legal definitions, corporate approaches, and media portrayals of sexual harassment in these two countries. Currently, she is examining how moral concerns about body weight, eating, and exercise shape public debates over obesity and the consequences different "body weight frames" have for social inequality.

\section{REFERENCES}

Badinter, Elisabeth. 1994. "Ici, en droit, nous avons tout obtenu." Le Nouvel Observateur, May 19, pp. $102-5$.

Bagdikian, Ben H. 2000. The Media Monopoly. Boston, MA: Beacon Press.

Baker, C. Edwin. 1994. Advertising and a Democratic Press. Princeton, NJ: Princeton University Press.

Banton, Michael. 1994. "Effective Implementation of the UN Racial Convention." New Community 20:475-87.

Barber, Benjamin J. 1995. Jihad vs. McWorld. New York: Ballantine Books.

Barnhurst, Kevin G. and John Nerone. 2001. The Form of News: A History. New York: The Guilford Press.

Beckett, Katherine. 1996. "Culture and the Politics of Signification: The Case of Child Sexual Abuse." Social Problems 43:57-76.

Bennett, W. Lance. 1983. News : The Politics of Illusion. New York: Longman.

Benson, Rodney. 1999. "Field Theory in Comparative Context: A New Paradigm for Media Studies." Theory and Society 29: 463-498.

- 2000. Shaping the Public Sphere: Journalistic Fields and Immigration Debates in the United States and France, 1973-1994. Ph.D.
Dissertation, Department of Sociology, University of California, Berkeley, CA.

2004. "Bringing the Sociology of Media

Back In." Political Communication, 21: 275-92.

2005. "Mapping Field Variation:

Journalism in France and the United States." In R.

Benson and E. Neveu, Eds. Bourdieu and the Journalistic Field. Cambridge, England: Polity Press.

Bernard, Philippe. 1991. "Harkis: au nom des pères." Le Monde, July 10, p. 1.

Best, Joel. 2001. "The Diffusion of Social Problems." In J. Best, Ed., How Claims Spread: CrossNational Diffusion of Social Problems. New York: Aldine de Gruyter.

Blatt, David Stuart. 1996. Immigration Politics and Immigrant Collective Action in France, 1968-1993.

Ph.D. Dissertation, Department of Government, Cornell University, Ithaca, NY.

Bleich, Erik. 2001. "The French Model: Color-Blind Integration.” In J. D. Skrentny, Ed., Color Lines: Affirmative Action, Immigration and Civil Rights for America. Chicago, IL: University of Chicago Press.

Bobin, Frederic. 1992. "Le projet de loi de Mme Neiertz au Palais du Luxembourg les sénateurs approuvent la lutte contre le harcèlement sexuel et "étendent à la fonction publique." Le Monde, May 23.

Body-Gendrot, Sophie and Martin A. Schain. 1992.

"National and Local Politics and the Development of Immigration Policy in the United States and France: A Comparative Analysis." In D.L. Horowitz and G. Noiriel, Eds., Immigrants in Two Democracies: French and American Experience. New York: New York University Press.

Boltanski, Luc. 1987. The Making of a Class: Cadres in French Society. Cambridge, England/ Paris: Cambridge University Press and Maison des Sciences de L'Homme.

Bonnafous, Simone. 1991. L'Immigration Prise aux Mots: Les immigrés dans la presse au tournant des années 80. Paris, France: éditions Kimé.

Bornstein, Stephen E. 1990. "The Politics of Scandal." In Peter A. Hall, Jack Hayward, and Howard Machin, Eds., Developments in French Politics. London, England: MacMillan.

Bourdieu, Pierre. 1993. The Field of Cultural Production. New York: Columbia University Press. 1998. On Television and Journalism. London, England: Pluto Press.

Brinkley, Joel. 1994. "At Immigration, Disarray and Defeat; Chaos at the Gates-First of five articles," The New York Times, September 11, p. 1.

Brubaker, Rogers. 1992. Citizenship and Nationhood in France and Germany. Cambridge, MA: Harvard University Press.

Calavita, Kitty. 1996. "The New Politics of Immigration: 'Balanced-Budget Conservativism' 
and the Symbolism of Proposition 187." Social Problems 43:284-305.

Castells, Manuel. 1997. The Power of Identity; Volume II: The Information Age: Economy, Society, and Culture. Oxford, England: Blackwell Publishers.

Caton. 1983. "Caton: 'A l'heure des urnes, il n'y a plus d'hommes politiques, mais des comptables'." Libération, September 13, p. 5.

Champagne, Patrick. 2005. “The 'Double Dependency': The Journalistic Field Between Politics and Markets." In R. Benson and E. Neveu, Eds., Bourdieu and the Journalistic Field. Cambridge, England: Polity Press.

Clark, Priscilla Parkhurst. 1987. Literary France: The Making of a Culture. Berkeley, CA: University of California Press.

Colson, Marie-Laure and Christine Fauvet-Mycia. 1991. "Bianco: "Chirac a un culot d'acier'." Libération, June 21.

Cornelius, Wayne A., Philip L. Martin, and James F. Hollifield. 1995. "Introduction: The Ambivalent Quest for Immigration Control.” In Cornelius et al., Eds., Controlling Immigration. Stanford, CA: Stanford University Press.

Coste, Philippe. 1995. "L'Amérique sexuellement correct." L'Express, Histoires, February 9, p. 58.

Courtois, Gérard, "En France, par convention, la viel privée des hommes politiques est respectéell Lei Monde, September 17, 1998, p. 7.

de Pisan, Annie and Anne Tristan. 1977. Histoires Du $M L F$. Preface by Simone de Beauvoir. Paris, France: Calmann-Lévy.

de Tarlé, Antoine. 1980. "The Press and the State in France." In A. Smith, Ed., Newspapers and Democracy. Cambridge, MA: MIT Press.

Desrosières, Alain and Laurent Thévenot. 1988. Les Catégories Socio-Professionelles. Paris, France: La Découverte.

Derieux, Emmanuel. 2001. Droit des Médias. Paris, France: Dalloz.

Deuze, Mark. 2002. "National News Cultures: A Comparison of Dutch, German, British, Australian, and U.S. Journalists." Journalism and Mass Communication Quarterly 79(1):134-149.

Devillard, Valérie, Marie-Françoise Lafosse, Christine Leteinturier, and Rémy Rieffel. 2001. Les journalistes français à l'aube de l'an 2000: Profils et parcours. Paris, France: Panthéon-Assas.

DiMaggio, Paul J. and Walter W. Powell. 1991. "The Iron Cage Revisited : Institutional Isomorphism and Collective Rationality in Organizational Fields." In W.W. Powell and P.J. DiMaggio, Eds., The New Institutionalism in Organizational Analysis. Chicago, IL: University of Chicago Press.

Dubet, Francois. 1989. Immigrations: Qu'en savons nous? Un bilan des Connaissances. Paris, France: La Documentation Française.

Engelberg, Stephen. 1994. “In Immigration
Labyrinth, Corruption Comes Easily." The New York Times. September 12, p. 1.

Entman, Robert M. 1993. "Framing: Toward Clarification of a Fractured Paradigm." Journal of Communication 43(4): 51-58.

Esser, Frank. 1998. "Editorial Structures and Work Principles in British and German Newsrooms." European Journal of Communication 13(3):375-405.

1999. “'Tabloidization' of News: A Contemporary Analysis of Anglo-American and German Press Journalism.” European Journal of Communication 14(3):291-324.

Eveno, Patrick. 1996. Le Monde 1944-1995: Histoire d'une enterprise de presse. Paris, France: Le Monde-éditions.

Fantasia, Rick. 1995. "Fast Food in France." Theory and Society 24:201-43.

Fassin, Eric. 1999. "'Good to Think': The American Reference in French Discourses of Immigration and Ethnicity." In C. Joppke and S. Lukes, Eds., Multicultural Questions. Oxford, England: Oxford University Press.

Faure, Christine and Tom Bishop, Eds. 1992. L'Amerique des Francais. Paris, France: Editions Francois Bourin.

Favell, Adrian. 2001. Philosophies of Integration : Immigration and the Idea of Citizenship in France and Britain. New York: Palgrave Macmillan.

Favereau, Eric. 1983. "Le dernier must de tout-Etat: 'Beur is beautiful'." Libération, December 1, p. 14.

Ferree, Myra Marx, William Anthony Gamson, Jürgen Gerhards and Dieter Rucht. 2002. Shaping Abortion Discourse: Democracy and the Public Sphere in Germany and the United States. Cambridge, England: Cambridge University Press.

Fetzer, Joel S. 2000. Public Attitudes toward Immigration in the United States, France, and Germany. Cambridge, England: Cambridge University Press.

Frappat, Bruno. 1991. “Trop.” [sub-title underneath: "La polémique sur l'immigration; Mme Cresson dénounce les propos de M. Chirac"]. Le Monde. June 21, p. 1.

Freiberg, J.W. 1981. French Press: Class, State, and Ideology. New York: Praeger Publishers.

Friedland, Roger and Robert R. Alford. 1991. "Bringing Society Back In: Symbols, Practices, and Institutional Contradictions." In P. J. DiMaggio and W.W. Powell, Eds., The New Institutionalism in Organizational Analysis. Chicago, IL: University of Chicago Press.

Gamson, William and Andre Modigliani. 1989. "Media Discourse and Public Opinion on Nuclear Power: A Constructionist Approach." American Journal of Sociology 95:1-37.

Gans, Herbert J. 1995. The War Against the Poor. New York: Basic Books.

Gastaut, Yvan. 1995. "Les mutations du thème de 
l'immigration dans le journal Le Monde (1958-1992); Etude d'un corpus d'articles." Migrations-Sociètè: 40-51.

Gauthier, Ursula. 1999. "Suède: La fin des filles publiques." Le Nouvel Observateur, January 14, Notre Epoque, p. 86.

Giesbert, Franz Olivier. 1991. "La tyrannie des autruches." Le Figaro, July 9, p. 1.

Gilens, Martin. 1999. Why Americans Hate Welfare. Chicago, IL: University of Chicago Press.

Gilson, Martine. 1989. "Le retour du droit du cuissage." Le Nouvel Observateur, March 2.

Giroud, Françoise. 1997. "Sexuellement incorrect. " Le Nouvel Observateur, Television, 19 September, p. 5.

Gordon, Philip H. and Sophie Meunier. 2001. The French Challenge: Adapting to Globalization. Washington, DC: Brookings Institution Press.

Guillén, Mauro F. 2001. "Is Globalization Civilizing, Destructive or Feeble? A Critique of Five Key Debates in the Social Science Literature." Annual Review of Sociology 27:235-60.

Gurevitch, Michael, Mark R. Levy, and Itzhak Roeh. 1991. "The Global Newsroom: Convergences and Diversities in the Globalization of Television News.” In P. Dahlgren and C. Sparks, Eds., Communication and Citizenship. London, England: Routledge.

Hallin, Daniel C. and Paolo Mancini. 1984. "Speaking of the President: Political Structure and Representational Form in U.S. and Italian Television News." Theory and Society 13:829-50. 2004. Comparing Media Systems: Three Models of Media and Politics. Cambridge, England: Cambridge University Press.

Hargreaves, Alec. 1995. Immigration, 'Race' and Ethnicity in Contemporary France. London, England and New York: Routledge.

Harris, Louis. 1991. Le harcèlement sexuel: Enquête des français: perceptions, opinions et évaluation du phénomène. Published by the European Union. Herman, Edward S. and Robert W. McChesney. 1997. The Global Media. London, England and New York: Continuum.

INSEE. 1998. "Enquete Emploi." (Employment Survey).

Jenkins, Philip. 1992. Intimate Enemies: Moral Panics in Contemporary Great Britain. Hawthorne, NY: Aldine de Gruyter.

Kuhn, Raymond. 1995. The Media in France. London, England and New York: Routledge.

Kuisel, Richard. 1993. Seducing the French: The Dilemma of Americanization. Berkeley, CA: University of California Press.

Lamont, Michèle. 1987. "How to Become a Dominant French Philosopher: The Case of Jacques Derrida." American Journal of Sociology 93:584-622.
Morality and the Boundaries of Race, Class, and Immigration. Cambridge, MA: Harvard University Press.

Lamont, Michèle and Laurent Thévenot, Eds. 2000. Rethinking Comparative Cultural Sociology: Repertoires of Evaluation in France and the United States. Cambridge, England: Cambridge University Press.

Lee, Ellie. 2001. "Reinventing Abortion as a Social Problem: 'Postabortion Syndrome' in the United States and Britain.” In J. Best, Ed., How Claims Spread. Hawthorne, NY: Aldine de Gruyter.

Le Figaro. 1991. "Giscard: 'Ouvrir les yeux et réfléchir'.” September 23, p. 6.

Le Monde staff writer. 1998. "HARCELEMENT: André Labarrère est accusé de harcèlement sexuel par un ancien employé de la société béarnaise d'économie mixte pour l'habitat (SBEMH)." Le Monde, April 27.

McQuail, Denis. 1994. Mass Communication Theory: An Introduction. London, England: Sage.

Mir, Edouard. 1991. "Editorial: La Logique du Ghetto." Libération, March 28, p. 3.

Molotch, Harvey and Marilyn Lester. 1974. "News as Purposive Behavior: On the Strategic Use of Routine Events, Accidents, and Scandals."

In Amerioan Sociological Review 39:101-12.

NNewspaper Association of America. 2001. 2001 . Circulation Facts, Figures and Logic. (accessed via internet, April 2004).

Noiriel, Gérard. 1996. The French Melting Pot: Immigration, Citizenship and National Identity. Translated by Geoffroy de Laforcade. Minneapolis, MN: University of Minnesota.

Normand, Jean-Michel. 1991. "L'example de la Goutte-d'Or ou les mauvais comptes du maire de Paris." Le Monde, June 22, p. 9.

O'Connor, Julia S., Ann Shola Orloff, and Sheila Shaver. 1999. States, Markets, Families: Gender, Liberalism and Social Policy in Australia, Canada, Great Britain and the United States. Cambridge, England: Cambridge University Press.

Padioleau, Jean G. 1985. Le Monde et le Washington Post. Paris, France: Presses Universitaires de France.

Pandraud, Robert. 1991. Quotation in "Les réactions." Libération, June 11, p. 35.

Patterson, Thomas E. and Wolfgang Donsbach. 1996. "News Decisions: Journalists as Partisan Actors." Political Communication 13:455-468.

Peyrefitte, Alain. 1991. "Penser l'immigration : les trois solutions." Le Figaro, September 26, p. 8.

Picq, Françoise. 1993. Libération des femmes: les années-mouvement. Paris, France: Seuil.

Portes, Alejandro and Rubén G. Rumbaut. 1996. Immigrant America: A Portrait. Berkeley, CA: University of California Press.

Reinhold, Robert. 1986. "Flow of 3d World 
Immigrants Alters Weave of U.S. Society." The New York Times, June 30, p. A-1.

Rivaud, Francine. 1990. "Canapé Sans Promotion." Le Nouvel Observateur, December 6.

Ryan, Charlotte. 1991. Prime Time Activism. Boston, MA: South End Press.

Sacco, Vincent F. and Karim Ismaili. 2001. "Social Problems Claims and the Undefended Border: The Case of Canada and the United States." In J. Best, Ed., How Claims Spread. Hawthorne, NY: Aldine de Gruyter.

Saguy, Abigail C. 2000. "Employment Discrimination or Sexual Violence?: Defining Sexual Harassment in American and French Law." Law and Society Review 34(4).

- 2002. "Sexual Harassment in the News: The United States and France." The Communication Review 5(2):109-41.

- 2003. What Is Sexual Harassment? From Capitol Hill to the Sorbonne. Berkeley: University of California Press.

Saranga, Karen. 1995. "En France, Il Faut Des Preuves.” L'Express, February 9, p. 59.

Schifres, Alain. 1985. "Touche Pas a Ma P ... Te." Le Nouvel Observateur, October 1, p. 48.

Schudson, Michael. 1995. The Power of News. Cambridge, MA: Harvard University Press.

Scott, Joan W. 1997. "'La Querelle Des Femmes' in the Late Twentieth Century." New i eft Review(226):3-19.

Shoemaker, Pamela J. and Stephen D. Reese. 1991. Mediating the Message: Theories of Influences on Mass Media Content. New York: Longman.

Skrentny, John David., Ed. 2001. Color Lines: Affirmative Action, Immigration, and Civil Rights Options for America. Chicago, IL: University of Chicago Press.

Solé, Robert. 1991. "La politique de la ville et la violence dans les banlieues; Les députés examinent la loi 'anti-ghettos." Le Monde, May 29, p. 1.

2002. "Plainte et chuchotements." Le Monde, Analyses \& Forum, February 17.

Sontag, Deborah and Stephen Engelberg. 1994. "Insider's View of the INS: 'Cold, Rude and Insensitive'.” The New York Times, September 15, p. 1.
Sreberny-Mohammadi, Annabelle. 2000. "The Global and Local in International Communications." In J. Curran and M. Gurevitch, eds., Mass Media and Society, 3rd edition. London, England: Arnold.

Steinberg, Stephen. 1981. The Ethnic Myth: Race, Ethnicity, and Class in America. Boston, MA: Beacon Press.

Swidler, Anne. 2001. Talk of Love: How Culture Matters. Chicago, IL: University of Chicago Press.

Thogmartin, Clyde. 1998. The National Daily Press of France. Birmingham, AL: Summa Publications.

Thompson, John B. 2000. Political Scandal: Power and Visibility in the Media Age. Cambridge, England: Polity Press.

Tibon-Cornillot, Michel. 1983. "Le défi de l'immigration maghrébine: Une amnésie ordinaire." Le Monde, August 23, p. 1.

Tilly, Charles. 1986. The Contentious French. Cambridge, MA: Harvard University Press.

Tribalat, Michèle. 1995. Faire France. Paris, France: La Découverte/Essais.

Tunstall, Jeremy. 1977. The Media are American. London, England: Constable.

U.S. Merit Systems Protection Board. 1981. Sexual Harassment in the Federal Workforce: Is It a Problem? Washington, DC: U.S. Government Printing Office.

Verhovek, Sam Howe. 1994. "Stop Benefits for Aliens? It Wouldn't Be That Easy." The New York Times, June 8, p. A-1.

Vichniac, Judith E. 1991. "French Socialists and Droit à la Différence: A Changing Dynamic." French Politics \& Society 9:40-56.

Victor, Jeffrey S. 1998. "Moral Panics and the Social Construction of Deviant Behavior: A Theory and Application to the Case of Ritual Child Abuse." Sociological Perspectives 41:541-65.

Waisbord, Silvio. 2000. Watchdog Journalism in South America: News, Accountability, and Democracy. New York: Columbia University Press.

Weaver, David H., Ed. 1998. The Global Journalist: News People Around the World. Creskill, NJ: Hampton Press. 